p582 Flu fears: Asian nations may be ill-equipped to cope with a pandemic.

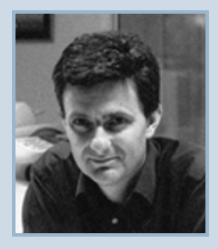

p586 No joke: Michael Malim's work has brought hope to HIV research.

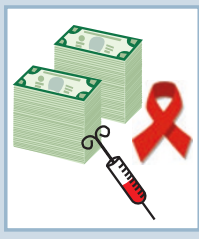

p587 Let down: AIDS researchers are upset about a massive NIH grant.

\title{
Vitamin guru provokes wRath of scientists, activists
}

A South African advertising campaign that touts multivitamins as a superior remedy for HIV/AIDS has set off a storm of international attention, with the United Nations condemning the ads as "wrong and misleading."

The campaign, led by physician and vitamin supplier Matthias Rath, says antiretroviral drugs are poisonous and extols the benefits of multivitamins to treat AIDS. In its marketing literature, the Rath Foundation implies endorsement from several international bodies, including the World Health Organization, UNICEF and UNAIDS.

The agencies have since issued a joint statement denouncing his claims, while researchers at the Harvard School of Public Health have accused Rath of "deliberately misinterpreting" certain findings.

Rath's full-page advertisements, some of which have run in The New York Times and The
International Herald Tribune, highlight a Harvard study in Tanzania that shows multivitamin supplements slowing AIDS progression.

The Harvard researchers say multivitamins should not be considered an alternative to anti-

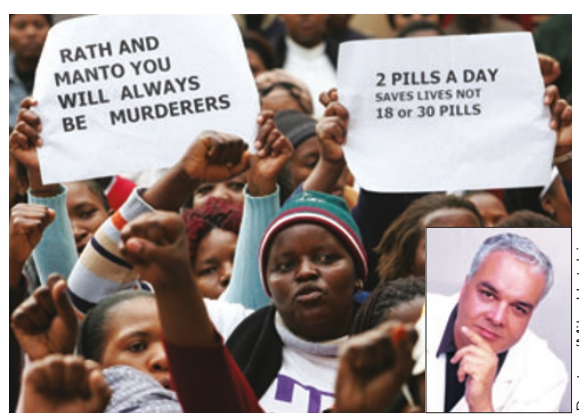

Drug war: South African activists protest against German doctor Matthias Rath (inset)

\section{AIDS denialists back on the upswing}

With his condemnation of antiretroviral therapy and the global "drug cartel," maverick doctor Matthias Rath has brought the AIDS dissident movement back into the world spotlight.

Comprising a loose worldwide network of scientists, journalists and activists, the dissidents have long contended that HIV does not cause AIDS and, like Rath, that AIDS drugs are akin to poison. Some members also argue that the virus has never been properly isolated.

Since 2000, when they successfully swayed South African President Thabo Mbeki with their views, dissident groups have largely faded from the public eye. But the movement is "most definitely" growing, says Valender Turner, a physician at the University of Western Australia and a leading member of the dissident 'Perth Group.'

Due to the movement's informal nature, it is unclear exactly how big their global community is. But on his website, botanist David Crowe, founder of the Alberta Reappraising AIDS Society, in May published the names of 2,192 people who question some or all aspects of the scientific consensus on AIDS. On the list are Nobel Laureate Kary Mullis, who developed the polymerase chain reaction method for amplifying DNA, and the University of CaliforniaBerkeley's Peter Duesberg, one of the first scientists to question HIV's role in causing AIDS.

Urging HIV-positive people away from antiretroviral drugs, dissident groups may also have contributed indirectly to another emerging trend: lawsuits.

In late 2004, for instance, a single mother in California filed suit against a physician for treating her child with the AIDS drug AZT after the child was accidentally pricked with a dirty needle. The woman also reportedly brought a case against GlaxoSmithKline, the drug's manufacturer, although the company would not confirm its involvement.

Crowe says he has recently spoken with several other people who are considering legal action over the prescription of AIDS medications. But most of the cases never get to court, he says, due to the dearth of available expert witnesses.

Meanwhile, mainstream AIDS researchers such as Cornell University's John Moore are incensed over the dissidents' claims. "I have nothing but contempt for these people," says Moore. "They have perverted their training to become scientific sociopaths."

Paroma Basu, Madison

retroviral therapy but a complementary intervention that is part of a comprehensive care package. "Antiretroviral therapy saves lives and its scale-up should be vigorously pursued in all countries," they said in a statement. The Rath Foundation did not respond to queries on the matter.

Concerns over the ads, as well as claims that the foundation has been running unregistered medical practices in Cape Town, have already sparked an investigation by South Africa's Medicines Control Council.

Meanwhile, a senior government minister has issued a colorfully worded statement telling Rath to get lost and comparing him to Hitler's chief propagandist Joseph Goebbels. Minister Kader Asmal was responding to an April letter from Rath to all members of Parliament accusing the Treatment Action Campaign (TAC), a prominent local group that lobbies for the rollout of free antiretrovirals, of being funded by "the pharmaceutical drug cartel".

The TAC is currently pursuing an interdict against Rath in the country's High Court and says it is planning to sue for defamation. The trial has already been delayed by the entry of the Traditional Healers' Organisation, which purports to represent the country's estimated 200,000 healers and is backing Rath in the case.

The organization accuses the TAC of promoting western drugs ahead of alternative remedies and acting as a front for pharmaceutical companies. However, TAC leader Zackie Achmat says he's willing to promote medicines from any source, providing they are scientifically proven as safe and effective (Nat. Med. 11, 6; 2005).

No traditional remedies have thus far been approved in the country, and one herbal mixture touted as a possible cure failed to clear tests at the Medical University of South Africa.

The spate of activity has no doubt added to the general confusion blighting South Africa's AIDS patients about how best to care for themselves. At a recent press conference, health minister Manto Tshabalala-Msimang reiterated her support for garlic, lemon and beetroot as important sources of nutrition and warned of the side effects of antiretrovirals. "Raw garlic and a skin of the lemon," she said, "not only do they give you a beautiful face and skin, but they also protect you from disease."

James Watson, London 